Original Research Paper

\title{
Vegetative Growth of Kale Land (Ipomoea reptans poir.) Due to Different doses of NPK and Bokashi Fertilizer
}

\author{
Ahmad Raksun ${ }^{1 *}$, Mahrus ${ }^{1}$ dan I Gde Mertha ${ }^{1}$ \\ ${ }^{1}$ Program Studi Pendidikan Biologi FKIP Universitas Mataram, Mataram, Indonesia
}

\author{
Article History \\ Received : March $12^{\text {th }}, 2020$ \\ Revised : July $27^{\text {th }}, 2020$ \\ Accepted : August $18^{\text {th }}, 2020$ \\ Published : August $21^{\text {th }}, 2020$ \\ *Corresponding Author: \\ Ahmad Raksun, \\ Program Studi Pendidikan \\ Biologi FKIP UNRAM \\ Email: \\ ahmadunram@unram.ac.id
}

\begin{abstract}
In order to maintain soil fertility, NPK fertilizer applications that have been carried out by farmer need to be combined with non chemical fertilizer such as bokashi. Research on vegetative growth of kale land due to NPK and bokashi fertilizer has been carried out in Bajur Village, West Lombok Regency. The purpose of this research was to detemine: (1) vegetative growth of kale land due to different doses of NPK fertilizer, (2) vegetative growth of kale land due to different doses of bokashi, (3) the effect of interaction of NPK and bokashi fertilizer on growth of kale land, (4) Optimum dose of NPK fertilizer and bokashi for kale land. This research used 2 factors design. The first factor is the dose of NPK fertilizer and the second factors is the dose of bokashi. The growth parameters measured were stem height, leaf length, leaf width and number of kale land leaf. Reseach data analyzed using analysis of variance. The results showed that: (1) NPK fertilizer treatment significantly affected stem height, leaf length and kale leaf width, but have no significant effect on the number of kale land leaves, (2) bokashi aplication significantly affected stem heght, leaf length and kale land leaf width but did not significantly affect the number of kale land leaves, (3) the interaction of NPK fertilizer and bokashi did not significantly affect all growth parameters measured, (4) the optimun dose of bokashi for kale land is $1,2 \mathrm{~kg}$ for $8 \mathrm{~kg}$ of soil and the optimum dose of NPK fertilizer is $1,5 \mathrm{~g}$ per plant. It is recommended that kale land famers use 1,2 $\mathrm{kg}$ bokashi for $8 \mathrm{~kg}$ of soil and 1,5 g NPK fertilizer per plant.
\end{abstract}

Keywords: bokashi; NPK fertilizer; growth of of kale land

\section{Pendahuluan}

Pertumbuhan dan produksi tanaman sangat ditentukan oleh sifat tanah dan ketersediaan unsur hara dalam tanah. Ketersediaan unsur hara akan semakin berkurang jika tanah ditanami terus-menerus tanpa memperhatikan pemeliharaan tanah yang dapat menyebabkan kesuburan tanah menurun (Sutedjo, 2010). Upaya meningkatkan ketersediaan unsur hara dapat dilakukan dengan pemupukan baik menggunakan pupuk organik maupun pupuk sintetik. Pemupukan memberikan kontribusi yang sangat luas dalam meningkatkan produksi dan kualitas produk yang dihasilkan. Salah satu efek pemupukan yang sangat bermanfaat yaitu meningkatnya kesuburan tanah yang menyebabkan tingkat produksi tanaman menjadi relatif stabil serta meningkatnya daya tahan tanaman terhadap serangan penyakit dan pengaruh iklim yang tidak menguntungkan. Selain itu pemupukan melengkapi persediaan unsur hara di dalam tanah sehingga kebutuhan tanaman terpenuhi (Pahan, 2008).

Pada saat ini pemupukan tanaman yang dilakukan masyarakat umumnya menggunakan pupuk kimia sintetik. Penggunaan pupuk organik dalam budidaya tanaman masih jarang dilakukan. Zulkarnain (2014) menjelaskan bahwa aplikasi input kimiawi yang berupa pupuk dan festisida sintetik dengan dosis tinggi tidak hanya berpengaruh menurunkan tingkat kesuburan tanah, tetapi juga mengakibatkan pada merosotnya keanekaragaman hayati, meningkatnya serangan hama dan penyakit, timbulnya hama yang resisten dan berkembangnya organisme parasit. Selain itu dampak negatif dari penggunaan infut kimiawi tidak hanya terbatas pada daerah pemakaian tetapi dapat menjadi makin luas melalui komponen rantai makanan seperti air minum, sayuran, buah-buahan dan produkproduk lain yang terkontaminasi.

Mencermati adanya dampak negatif penggunakaan pupuk sintetik terhadap menurunnya kesuburan tanah dan merosotnya keanekaragaman 
hayati maka diperlukan adanya upaya pengurangan punggunaan pupuk sintetik. Pemupukan tanaman dengan menggunakan kombinasi pupuk sintetik dan pupuk organik adalah salah satu upaya yang dapat dilakukan untuk mengurangi penggunaan pupuk sintetik. Salah satu pupuk organik yang dapat digunakan adalah bokashi yang dapat diproduksi dengan bahan baku sampah organik.

Pemupukan tanaman menggunakan bokashi sudah dilakukan pada sejumlah tanaman. Pemupukan menggunakan bokashi berpengaruh signifikan terhadap produksi cabai rawit, kadar optimum bokashi yang perlu diberikan pada lahan pertanian agar cabai rawit berproduksi secara optimal adalah $1,0 \mathrm{~kg}$ untuk setiap $10 \mathrm{~kg}$ tanah (Raksun dan Mertha, 2017). Pemupukan bokashi dengan dosis 20 ton per hektar memberikan bobot gabah kering per hektar tertinggi (4,70 ton), jumlah anakan produktif tertinggi $(25,00)$ dicapai varietas cianjur (Mulyana et al, 2011). Pemberian pupuk bokashi Eceng Gondok menunjukkan respon sangat nyata pada total produksi kedelai per plot (Hasibuan et al, 2017).

Berdasarkan uraian di atas maka dilakukan penelitian tentang pengaruh bokashi dan pupuk NPK terhadap pertumbuhan kangkung darat. Tujuan penelitian ini adalah untuk mengetahui: (1) pertumbuhan vegetatif kangkung darat akibat perlakuan pupuk NPK, (2) pertumbuhan vegetatif kangkung darat akibat ngaruh bokashi, (3) pengaruh interaksi bokashi dan pupuk NPK terhadap pertumbuhan kangkung darat, (4) dosis optimum bokashi dan pupuk NPK untuk tanaman kangkung darat.

\section{Bahan dan Metode}

\section{Waktu dan Tempat}

Penelitian ini telah dilaksanakan pada bulan Agustus sampai dengan Oktober 2019 di Desa Bajur Kecamatan Labuapi Kabupaten Lombok Barat. Bahanbahan yang digunakan adalah benih kangkung darat, bokashi, pupuk NPK, kertas label, insektisida, fungisida dan tanah sawah. Selanjutnya alat yang digunakan adalah timbangan, artco dorong, ember plastik, terpal, polybag, parang, cangkul, alat tulis menulis, gunting, karung goni, karung nilon, mesin pompa air, meteran, sekop dan hand sprayer.
Tahapan pelaksanaan penelitian adalah (1) pembuatan bokashi, (2) mengambil tanah sawah dan mengeringkannya di bawah terik matahari. (3) menghancurkan bongkahan tanah sawah yang sudah kering serta membuang sampah. batu dan kerikil yang ada pada tanah tersebut, (4) memasukkan tanah sawah ke dalam polybag berukuran $30 \mathrm{~cm}$ x $30 \mathrm{~cm}$ sebanyak $8 \mathrm{~kg}$ tanah per polybag. (5) memberikan bokashi pada setiap media tanah pada polybag sesuai dosis perlakuan, (6) membiarkan media tanah dan bokashi selama tiga minggu, (7) melakukan penanaman benih kangkung darat setelah tiga minggu perlakuan bokashi, (8) memberikan pupuk NPK setelah tanaman berumur delapan hari sesuiai dosis perlakuan (9) mengukur parameter pertumbuhan kangkung darat.

Dalam penelitian ini digunakan rancangan 2 faktor. Faktor pertama adalah dosis bokashi yang terdiri atas 5 level yaitu: $\mathrm{B}_{0}=0 \mathrm{~kg}$ bokashi (kontrol), $\mathrm{B}_{1}=$ pemberian $0,4 \mathrm{~kg}$ bokashi per polybag, $\mathrm{B}_{2}=$ pemberian $0,8 \mathrm{~kg}$ bokashi per polybag, $\mathrm{B}_{3}=$ pemberian $1,2 \mathrm{~kg}$ bokashi per polybag, $\mathrm{B}_{4}=$ pemberian $1,6 \mathrm{~kg}$ bokashi per polybag dan $\mathrm{B}_{5}=$ pemberian $2,0 \mathrm{~kg}$ bokashi per polybag. Faktor kedua adalah dosis pupuk NPK yang terdiri atas lima level yaitu $\mathrm{N}_{0}=0$ gram pupuk NPK per tanaman (kontrol), $\mathrm{N}_{1}=$ perlakuan 0,5 gram NPK per tanaman, $\mathrm{N}_{2}=$ perlakuan 1 gram NPK per tanaman, $\mathrm{N}_{3}=$ perlakuan 1,5 gram NPK per tanaman, $\mathrm{N}_{4}=$ perlakuan 2,0 gram NPK per tanaman. Perlakuan pupuk NPK dilakukan dengan melarutkannya pada setengah liter air (Toutenburg and Shalabh, 2009).

Parameter pertumbuhan yang diukur adalah tinggi batang, panjang helaian daun, lebar helaian daun dan jumlah helaian daun tanaman kangkung darat, yang diukur setelah tanaman kangkung darat berumur 24 hari. Data kuantitatif hasil pengukuran parameter di atas dianalisis dengan analisis sidik ragam (Toutenburg and Shalabh, 2009).

\section{Hasil dan Pembahasan}

\section{Tinggi Batang Kangkung Darat}

Hasil pengukuran parameter pertumbuhan menunjukkan bahwa kangkung darat memiliki tinggi batang, panjang helaian daun, lebar helaian daun dan jumlah helaian daun yang bervariasi pada masing-masing unit percobaan. Data hasil pengukuran tinggi batang kangkung darat umur 24 hari setelah tanam terdapat pada tabel 1 . 
Tabel 1. Rerata tinggi batang kangkung darat akibat perlakuan bokashi dan pupuk NPK pada umur 24 HST

\begin{tabular}{|c|c|c|c|}
\hline Perlakuan & Tinggi Batang $(\mathrm{cm})$ & Perlakuan & Tinggi Batang $(\mathrm{cm})$ \\
\hline $\mathrm{B}_{0} \mathrm{~N}_{0}$ & 18 & $\mathrm{~B}_{3} \mathrm{~N}_{0}$ & 21 \\
\hline $\mathrm{B}_{0} \mathrm{~N}_{1}$ & 19 & $\mathrm{~B}_{3} \mathrm{~N}_{1}$ & 22 \\
\hline $\mathrm{B}_{0} \mathrm{~N}_{2}$ & 19 & $\mathrm{~B}_{3} \mathrm{~N}_{2}$ & 24 \\
\hline $\mathrm{B}_{0} \mathrm{~N}_{3}$ & 20 & $\mathrm{~B}_{3} \mathrm{~N}_{3}$ & 26 \\
\hline $\mathrm{B}_{0} \mathrm{~N}_{4}$ & 19 & $\mathrm{~B}_{3} \mathrm{~N}_{4}$ & 20 \\
\hline $\mathrm{B}_{1} \mathrm{~N}_{0}$ & 19 & $\mathrm{~B}_{4} \mathrm{~N}_{0}$ & 21 \\
\hline $\mathrm{B}_{1} \mathrm{~N}_{1}$ & 20 & $\mathrm{~B}_{4} \mathrm{~N}_{1}$ & 23 \\
\hline $\mathrm{B}_{1} \mathrm{~N}_{2}$ & 21 & $\mathrm{~B}_{4} \mathrm{~N}_{2}$ & 24 \\
\hline $\mathrm{B}_{1} \mathrm{~N}_{3}$ & 22 & $\mathrm{~B}_{4} \mathrm{~N}_{3}$ & 24 \\
\hline $\mathrm{B}_{1} \mathrm{~N}_{4}$ & 20 & $\mathrm{~B}_{4} \mathrm{~N}_{4}$ & 20 \\
\hline $\mathrm{B}_{2} \mathrm{~N}_{0}$ & 20 & $\mathrm{~B}_{5} \mathrm{~N}_{0}$ & 21 \\
\hline $\mathrm{B}_{2} \mathrm{~N}_{1}$ & 21 & $\mathrm{~B}_{5} \mathrm{~N}_{1}$ & 21 \\
\hline $\mathrm{B}_{2} \mathrm{~N}_{2}$ & 22 & $\mathrm{~B}_{5} \mathrm{~N}_{2}$ & 22 \\
\hline $\mathrm{B}_{2} \mathrm{~N}_{3}$ & 23 & $\mathrm{~B}_{5} \mathrm{~N}_{3}$ & 21 \\
\hline $\mathrm{B}_{2} \mathrm{~N}_{4}$ & 22 & $\mathrm{~B}_{5} \mathrm{~N}_{4}$ & \\
\hline & & & \\
\hline
\end{tabular}

Pada tabel 1 dapat dilihat bahwa batang kangkung darat tertinggi adalah $26 \mathrm{~cm}$ terdapat pada perlakuan $\mathrm{B}_{3} \mathrm{~N}_{3}$ yaitu perlakuan $1,2 \mathrm{~kg}$ bokashi per $8 \mathrm{~kg}$ tanah dan $1,5 \mathrm{gram}$ pupuk NPK yang dilarutkan dalam 1 liter air. Batang terpendek kangkung darat adalah $18 \mathrm{~cm}$, terdapat pada perlakuan $\mathrm{B}_{0} \mathrm{~N}_{0}$ yaitu perlakuan $0 \mathrm{~kg}$ bokashi dan 0 gram pupuk NPK. Seanjutnya hasil analisis sidik ragam tinggi batang terdapat pada tabel 2 .

Tabel 2. Hasil analis sidik ragam pengaruh perbedaan dosis bokashi dan pupuk NPK terhadap tinggi batang kangkung darat.

\begin{tabular}{|l|c|c|c|c|c|}
\hline \multicolumn{1}{|c|}{ Sumber Keragaman } & DB & JK & KT & F. Hitung & $\begin{array}{c}\text { F. tabel } \\
0,05\end{array}$ \\
\hline Ulangan & 2 & 0,87 & 0,435 & & \\
\hline Perlakuan & 29 & 321,6 & 11,09 & & \\
\hline Bokashi (B) & 5 & 206,4 & 41,28 & 17,2 & 2,38 \\
\hline Pupuk NPK (N) & 4 & 91,6 & 22,9 & 9,54 & 2,52 \\
\hline B x N & 20 & 23,6 & 1,18 & 0,49 & 1,76 \\
\hline Galat & 58 & 139,13 & 2,4 & & \\
\hline Umum & 89 & 461,8 & 5,19 & & \\
\hline
\end{tabular}

Hasil analisis sidik ragam pengaruh perlakuan bokashi dan pupuk NPK terhadap tinggi batang kangkung darat pada tabel 2 menunjukkan bahwa perlakuan bokashi berpengaruh nyata terhadap tinggi batang kangkung darat. Perlakuan pupuk NPK berpengaruh nyata terhadap tinggi batang kangkung darat. Interaksi bokashi dan pupuk NPK tidak berpengaruh nyata terhadap tinggi batang kangkung darat. Adanya pengaruh nyata aplikasi bokashi terhadap tinggi batang kangkung darat dimungkinkan karena pemberian bokashi pada lahan pertanian dapat meningkatkan ketersediaan usnsur hara dalam tanah. Setyastika dan Suntari (2019) melaporkan bahwa pemberian bokashi dapat meningkatkan P-tersedia pada 60 HSI, serta $\mathrm{N}$ total dan $\mathrm{NO}_{3}^{-}$pada 30 dan 60 HSI dibandingkan dengan kontrol. Media terbaik untuk pertumbuhan semai eboni adalah pupuk organik EM bokashi karena media ini dapat meningkatkan solubilitas dan viabilitas hara dalam tanah dan memberikan pertumbuhan semai eboni yang optimal (Sumiasri dan Setyowati, 2006).

Hasil penelitian ini sejalan dengan hasil peneitian yang dilakukan Raksun dan Japa (2018) yang menyimpulkan bahwa aplikasi bokashi berpengaruh nyata terhadap tinggi batang kacang panjang. Demikian juga Ryan (2010) menyimpulkan bahwa penggunaan bokashi EM4 memberikan pengaruh terhadap penambahan tinggi tanaman umur 3 dan 4 minggu setelah tanam serta produksi (berat basah) tanaman sawi. Penggunaan bokashi EM 4 dapat meningkatkan efisiensi pemakaian pupuk kimia. Pemberian dosis kombinasi pupuk kimia (NPK 75\%) dengan penambahan bokashi EM 4 merupakan pilihan terbaik untuk diterapkan oleh petani sawi. 
Penggunaan pupuk organik berpengaruh nyata terhadap parameter tinggi batang tanaman, diameter batang, indeks luas daun, panjang tongkol dan bobot segar tongkol per hektar tanaman jagung manis (Nurcahya et al 2017). Pemberian pupuk organik bokashi berpengaruh nyata terhadap tinggi tanaman kedelai (Simatupang, 1999). Pemberian bokashi berpengaruh sangat nyata terhadap tinggi dan berat segar tanaman caisin (Tomia, 2012).

Perlakuan pupuk NPK juga berpengaruh nyata terhadap tinggi batang kangkung darat. Hasil yang sama pengaruh perlakuan pupuk NPK terhadap tinggi batang ditemukan pada penelitian sebelumnya pada tanaman melon. Aplikasi pupuk NPK berpengaruh nyata terhadap tinggi batang melon. Rerata tinggi batang tanaman melon tertinggi yang diukur 24 hari setelah tanam adalah $73 \mathrm{~cm}$ terdapat pada perlakuan 5 gram pupuk NPK yang diberikan sebanyak 3 kali. Tinggi batang melon terendah adalah $58 \mathrm{~cm}$, terdapat pada perlakuan kontrol (Raksun et al, 2019). Pupuk NPK berpengaruh nyata terhadap pertumbuhan tinggi dan diameter batang semai Gmelina. Perlakuan kombinasi NPK 10 gr dan kompos 30 gr memberikan pengaruh paling nyata dan respon pertumbuhan tertinggi terhadap kontrol yaitu 70,08\% atau setara dengan rata-rata pertumbuhan sebesar 7,56 cm terhadap control (Waris dan Fathia 2010). Pemberian pupuk NPK mutiara berpengaruh nyata terhadap pertumbuhan. Perlakuan terbaik terdapat pada perlakuan 250 g/plot. menghasilkan tinggi tanaman tertinggi 35,28 $\mathrm{cm}$ (Efendi et al., 2017). Tinggi tanaman, diameter batang dan jumlah cabang produktif, tanaman terung memberikan respons positif terhadap aplikasi pupuk $\mathrm{N}, \mathrm{P}, \mathrm{K}$ (Firmansyah et al., 2017). pemberian pupuk NPK dosis 2 g/tanaman memberikan pengaruh yang baik terhadap pertumbuhan tinggi tanaman, jumlah daun dan diameter batang bibit kakao. Kombinasi pemberian perlakuan kompos ampas tahu dosis $225 \mathrm{~g} /$ tanaman dan pupuk NPK dosis $2 \mathrm{~g} /$ tanaman memberikan pengaruh yang baik terhadap pertumbuhan tinggi bibit bibit kakao (Daryadi dan Ardian, 2017)

\section{Panjang Daun}

Data hasil pengukuran panjang helaian daun kangkung darat terdapat pada tabel 3. Data tersebut menunjukkan bahwa panjang helaian daun kangkung darat tertinggi adalah $142 \mathrm{~mm}$, terdapat pada perlakuan $\mathrm{B}_{3} \mathrm{~N}_{3}$ dan $\mathrm{B}_{3} \mathrm{~N}_{4}$ yaitu kombinasi perlakuan 1,2 kg bokashi per 8 kg tanah dengan 1,5 atau 2,0 gram pupuk NPK. Panjang helaian daun kangkung darat terpendek adalah $128 \mathrm{~mm}$, terdapat pada perlakuan $\mathrm{B}_{0} \mathrm{~N}_{0}$ yaitu perlakuan $0 \mathrm{~kg}$ bokashi dan 0 gram pupuk NPK.

Tabel 3. Rerata panjang helaian daun kangkung darat akibat perlakuan bokashi dan pupuk NPK pada umur 24 HST

\begin{tabular}{|c|c|c|c|}
\hline Perlakuan & $\begin{array}{c}\text { Panjang Helaian Daun } \\
(\mathrm{mm})\end{array}$ & Perlakuan & $\begin{array}{c}\text { Panjang Helaian Daun } \\
(\mathrm{mm}))\end{array}$ \\
\hline $\mathrm{B}_{0} \mathrm{~N}_{0}$ & 128 & $\mathrm{~B}_{3} \mathrm{~N}_{0}$ & 135 \\
\hline $\mathrm{B}_{0} \mathrm{~N}_{1}$ & 130 & $\mathrm{~B}_{3} \mathrm{~N}_{1}$ & 136 \\
\hline $\mathrm{B}_{0} \mathrm{~N}_{2}$ & 131 & $\mathrm{~B}_{3} \mathrm{~N}_{2}$ & 139 \\
\hline $\mathrm{B}_{0} \mathrm{~N}_{3}$ & 132 & $\mathrm{~B}_{3} \mathrm{~N}_{3}$ & 142 \\
\hline $\mathrm{B}_{0} \mathrm{~N}_{4}$ & 131 & $\mathrm{~B}_{3} \mathrm{~N}_{4}$ & 133 \\
\hline $\mathrm{B}_{1} \mathrm{~N}_{0}$ & 130 & $\mathrm{~B}_{4} \mathrm{~N}_{0}$ & 134 \\
\hline $\mathrm{B}_{1} \mathrm{~N}_{1}$ & 131 & $\mathrm{~B}_{4} \mathrm{~N}_{1}$ & 137 \\
\hline $\mathrm{B}_{1} \mathrm{~N}_{2}$ & 131 & $\mathrm{~B}_{4} \mathrm{~N}_{2}$ & 140 \\
\hline $\mathrm{B}_{1} \mathrm{~N}_{3}$ & 134 & $\mathrm{~B}_{4} \mathrm{~N}_{3}$ & 138 \\
\hline $\mathrm{B}_{1} \mathrm{~N}_{4}$ & 133 & $\mathrm{~B}_{4} \mathrm{~N}_{4}$ & 133 \\
\hline $\mathrm{B}_{2} \mathrm{~N}_{0}$ & 131 & $\mathrm{~B}_{5} \mathrm{~N}_{0}$ & 134 \\
\hline $\mathrm{B}_{2} \mathrm{~N}_{1}$ & 133 & $\mathrm{~B}_{5} \mathrm{~N}_{1}$ & 136 \\
\hline $\mathrm{B}_{2} \mathrm{~N}_{2}$ & 134 & $\mathrm{~B}_{5} \mathrm{~N}_{2}$ & 137 \\
\hline $\mathrm{B}_{2} \mathrm{~N}_{3}$ & 135 & $\mathrm{~B}_{5} \mathrm{~N}_{3}$ & 135 \\
\hline $\mathrm{B}_{2} \mathrm{~N}_{4}$ & 135 & $\mathrm{~B}_{5} \mathrm{~N}_{4}$ & \\
\hline
\end{tabular}

Hasil analisis sidik ragam pengaruh perlakuan bokashi dan pupuk NPK terhadap panjang helaian daun kangkung darat pada tabel 4 menunjukkan bahwa perlakuan bokashi berpengaruh nyata terhadap panjang helaian daun kangkung darat. Perlakuan pupuk NPK berpengaruh nyata terhadap panjang helaian kangkung darat. Interaksi bokashi dan pupuk NPK tidak berpengaruh nyata terhadap panjang helaian daun kangkung darat. 
Tabel 4. Hasil analis sidik ragam pengaruh perbedaan dosis bokashi dan pupuk NPK terhadap panjang helaian daun kangkung darat.

\begin{tabular}{|l|c|c|c|c|c|}
\hline \multicolumn{1}{|c|}{ Sumber Keragaman } & DB & JK & KT & F. Hitung & $\begin{array}{c}\text { F. tabel } \\
0,05\end{array}$ \\
\hline Ulangan & 2 & 5,37 & 2,685 & & \\
\hline Perlakuan & 29 & 925,00 & 31,90 & & \\
\hline Bokashi (B) & 5 & 711,30 & 142,26 & 17,68 & 2,38 \\
\hline Pupuk NPK (N) & 4 & 192,50 & 48,13 & 5,98 & 2,52 \\
\hline B x N & 20 & 21,20 & 1,06 & 0,13 & 1,76 \\
\hline Galat & 58 & 466,63 & 8,05 & & \\
\hline Umum & 89 & 1397,00 & 15,70 & & \\
\hline
\end{tabular}

Adanya pengaruh nyata aplikasi bokashi terhadap panjang helaian daun kangkung darat dimungkinkan karena aplikasi bokashi pada media tanam dapat memperbaiki sifat fisika tanah. Trisno at al (2016) menyimpulkan bahwa pemberian bahan organik bokasi pupuk kandang sapi dapat meningkatkan indeks stabilitas agregat, porositas tanah, kadar air tanah jenuh dan kapasitas lapang. Adanya pengaruh nyata perlakuan bokashi terhadap panjang helaian daun juga ditemukan oleh Raksun dan japa (2019) pada tanaman kacang panjang. Hasil pengukuran panjang daun kacang panjang tertinggi adalah $114 \mathrm{~mm}$ terdapat pada perlakuan $1,2 \mathrm{~kg}$ bokashi per $1 \mathrm{~m}^{2}$ lahan pertanian. Panjang daun kacang panjang terendah adalah $95 \mathrm{~mm}$ terdapat pada perlakuan kontrol. Demikian juga pada tanaman melon Raksun et al (2019) menyimpulkan bahwa aplikasi pupuk organik bokashi berpengaruh nyata terhadap panjang daun melon. Dosis optimum pupuk organik bokashi untuk tanaman melon adalah 1,0 kg pupuk organik per $1 \mathrm{~m} 2$ lahan.

Penggunaan pupuk NPK juga berpengaruh signifikan terhadap pertumbuhan tanaman. Pemberian pupuk NPK 142 g (100\% dari dosis rekomendasi) meningkatkan panjang pelepah bibit pada umur 9 bulan, bobot kering tajuk dan bobot kering akar bibit kelapa sawit di main nursery. Terdapat interaksi antara pupuk NPK dan pupuk organik terhadap bobot kering akar bibit kelapa sawit di main nursery. Interaksi terbaik terdapat pada perlakuan pemberian pupuk NPK 50\% dan pupuk organik $36 \mathrm{~g}$ polibeg. Idha dan Herlina (2018) pada tanaman selada merah menunjukkan bahwa perlakuan pupuk kandang dan 3 gram pupuk NPK memberikan pertumbuhan terbaik dengan bobot segar konsumsi terbaik pula yaitu 118,10 gram per tanaman. Yousuf et al. (2014) melaporkan bahwa aplikasi pupuk $\mathrm{N}, \mathrm{P}$ dan $\mathrm{K}$ dapat meninkatkan pertumbuhan dan hasil tanaman. Tanaman coriander (Coriandrum sativum L.) menghasilkan produksi biji tertinggi (2,06 ton/ha pada tahun 2008-2009 dan 2,09 ton/ha pada tahun 2009-2010) diperoleh dari aplikasi moderat $\mathrm{N}, \mathrm{P}, \mathrm{K}$, dan $\mathrm{S}$ berturut-turut: 70, 50, 30, dan $20 \mathrm{~kg} / \mathrm{ha}$, dan produksi menurun dengan dosis yang lebih tinggi unsur hara tersebut. Produksi biji tertinggi seperti itu terkait dengan jumlah maksimum cabang primer per tanaman $(8,65)$ tercatat pada penggunaan N70P50K30S20 kg/ha. Unsur hara N, P, K, dan S berperan secara nyata meningkatkan pertumbuhan dan perkembangan tanaman coriander, percabangan maksimum yang berimplikasi pada produksi biji yang melimpah.

\section{Lebar Daun}

Perlakuan bokashi dan pupuk NPK menyebabkan terjadinya variasi lebar helaian daun kangkung darat. Pada tabel 5 dapat dilihat bahwa rerata lebar helaian daun terendah adalah $30 \mathrm{~mm}$ terdapat pada perlakuan $\mathrm{B}_{0} \mathrm{~N}_{0}$ dan $\mathrm{B}_{0} \mathrm{~N}_{1}$, yaitu perlakuan 0 gram bokasi yang dikombinasikan dengan 0 gram atau 0,5 gram pupuk NPK. Rerata lebar helaian daun tertinggi adalah $38 \mathrm{~mm}$ terdapat pada perlakuan $\mathrm{B}_{3} \mathrm{~N}_{3}$ dan $\mathrm{B}_{3} \mathrm{~N}_{4}$ ( perlakuan 1,2 kg bokashi yang dikombinasikan dengan 1,5 atau 2,0 gram pupuk NPK).

Tabel 5. Rerata lebar helaian daun kangkung darat akibat perbedaan dosis bokashi dan pupuk NPK pada umur 25 HST

\begin{tabular}{|c|c|c|c|}
\hline Perlakuan & $\begin{array}{c}\text { Lebar Helaian Daun } \\
(\mathrm{mm})\end{array}$ & Perlakuan & $\begin{array}{c}\text { Lebar Helaian Daun } \\
(\mathrm{mm}))\end{array}$ \\
\hline $\mathrm{B}_{0} \mathrm{~N}_{0}$ & 30 & $\mathrm{~B}_{3} \mathrm{~N}_{0}$ & 34 \\
\hline $\mathrm{B}_{0} \mathrm{~N}_{1}$ & 30 & $\mathrm{~B}_{3} \mathrm{~N}_{1}$ & 36 \\
\hline $\mathrm{B}_{0} \mathrm{~N}_{2}$ & 31 & $\mathrm{~B}_{3} \mathrm{~N}_{2}$ & 37 \\
\hline $\mathrm{B}_{0} \mathrm{~N}_{3}$ & 33 & $\mathrm{~B}_{3} \mathrm{~N}_{3}$ & 38 \\
\hline $\mathrm{B}_{0} \mathrm{~N}_{4}$ & 32 & $\mathrm{~B}_{3} \mathrm{~N}_{4}$ & 38 \\
\hline
\end{tabular}




\begin{tabular}{|c|c|c|c|}
\hline $\mathrm{B}_{1} \mathrm{~N}_{0}$ & 31 & $\mathrm{~B}_{4} \mathrm{~N}_{0}$ & 32 \\
\hline $\mathrm{B}_{1} \mathrm{~N}_{1}$ & 32 & $\mathrm{~B}_{4} \mathrm{~N}_{1}$ & 33 \\
\hline $\mathrm{B}_{1} \mathrm{~N}_{2}$ & 33 & $\mathrm{~B}_{4} \mathrm{~N}_{2}$ & 35 \\
\hline $\mathrm{B}_{1} \mathrm{~N}_{3}$ & 34 & $\mathrm{~B}_{4} \mathrm{~N}_{3}$ & 36 \\
\hline $\mathrm{B}_{1} \mathrm{~N}_{4}$ & 33 & $\mathrm{~B}_{4} \mathrm{~N}_{4}$ & 35 \\
\hline $\mathrm{B}_{2} \mathrm{~N}_{0}$ & 33 & $\mathrm{~B}_{5} \mathrm{~N}_{0}$ & 32 \\
\hline $\mathrm{B}_{2} \mathrm{~N}_{1}$ & 33 & $\mathrm{~B}_{5} \mathrm{~N}_{1}$ & 32 \\
\hline $\mathrm{B}_{2} \mathrm{~N}_{2}$ & 34 & $\mathrm{~B}_{5} \mathrm{~N}_{2}$ & 33 \\
\hline $\mathrm{B}_{2} \mathrm{~N}_{3}$ & 34 & $\mathrm{~B}_{5} \mathrm{~N}_{3}$ & 34 \\
\hline $\mathrm{B}_{2} \mathrm{~N}_{4}$ & 33 & $\mathrm{~B}_{5} \mathrm{~N}_{4}$ & 33 \\
\hline
\end{tabular}

Hasil analisis sidik ragam pengaruh perlakuan bokashi dan pupuk NPK terhadap lebar helaian daun kangkung darat pada tabel 6 menunjukkan bahwa perlakuan bokashi berpengaruh nyata terhadap lebar helaian daun kangkung darat. Perlakuan pupuk NPK berpengaruh nyata terhadap lebar helaian kangkung darat. Interaksi bokashi dan pupuk NPK tidak berpengaruh nyata terhadap panjang helaian daun kangkung darat.

Tabel 6. Hasil analis sidik ragam pengaruh perbedaan dosis bokashi dan pupuk NPK terhadap panjang helaian daun kangkung darat.

\begin{tabular}{|l|c|c|c|c|c|}
\hline \multicolumn{1}{|c|}{ Sumber Keragaman } & DB & JK & KT & F. Hitung & $\begin{array}{c}\text { F. tabel } \\
0,05\end{array}$ \\
\hline Ulangan & 2 & 2,6 & 1,3 & & \\
\hline Perlakuan & 29 & 364,4 & 12,57 & & \\
\hline Bokashi (B) & 5 & 65 & 13 & 3,29 & 2,38 \\
\hline Pupuk NPK (N) & 4 & 78,4 & 19,6 & 4,96 & 2,52 \\
\hline B x N & 20 & 221 & 11,05 & 2,79 & 1,76 \\
\hline Galat & 58 & 229,4 & 3,96 & & \\
\hline Umum & 89 & 596,4 & 6,70 & & \\
\hline
\end{tabular}

Adanya pengaruh nyata perlakuan bokashi terhadap lebar daun dimungkinkan karena bokashi adalah pupuk organik yang dapat memperbaiki sifat fisika tanah. Yuliarti (2009) menjelaskan bahwa penggunaan pupuk organik memiliki berbagai keunggulan dibandingkan pupuk kimia diantaranya dapat mengatur sifat fiska tanah dan dapat berperan sebagai penyangga persediaan unsur hara bagi tanaman sehingga pupuk ini dapat mengembalikan kesuburan tanah. Selanjutnya Sutedjo (2010) menyatakan bahwa penggunaan pupuk organik dapat meningkatkan kandungan unsur hara serta memperbaiki struktur tanah karena dapat merangsang perkembangan jasad renik di dalam tanah. Denga $\mathrm{n}$ demi kia $\mathrm{n}$ apabila diberikan dalam jumlah yang optimal akan dapat meningkatkan laju fotosintesis dan pertumbuhan tanaman.
Perlakuan Pupuk NPK juga berpengaruh nyata terhadap lebar daun kangkung darat. Hal ini disebabkan karena Pupuk NPK mengandung unsur hara nitrogen, phosfor dan kalium yang merupakan unsur hara makro yang dibutuhkan tanaman. Lingga dan Marsono (2013) menjelaskan bahwa unsur hara nitrogen merupakan komponen penyusun asam amino, protein dan pembentukan protoplasma sel yang dapat berfungsi dalam merangsang pertumbuhan tanaman. Fosfor berperan terhadap pembelahan sel pada titik tumbuh yang berpengaruh terhadap pertumbuhan tanaman.

\section{Jumlah Helaian Daun}

Data jumlah helain daun kangkung darat akibat perlakuan pupuk NPK dan bokashi disajikan pada tabel 7 . 
Tabel 7. Rerata jumlah helaian daun kangkung darat akibat perbedaan dosis bokashi dan pupuk NPK pada umur 25 HST

\begin{tabular}{|c|c|c|c|}
\hline Perlakuan & Jumlah Daun (helai) & Perlakuan & Jumlah Daun (helai)) \\
\hline $\mathrm{B}_{0} \mathrm{~N}_{0}$ & 6 & $\mathrm{~B}_{3} \mathrm{~N}_{0}$ & 7 \\
\hline $\mathrm{B}_{0} \mathrm{~N}_{1}$ & 8 & $\mathrm{~B}_{3} \mathrm{~N}_{1}$ & 7 \\
\hline $\mathrm{B}_{0} \mathrm{~N}_{2}$ & 7 & $\mathrm{~B}_{3} \mathrm{~N}_{2}$ & 7 \\
\hline $\mathrm{B}_{0} \mathrm{~N}_{3}$ & 8 & $\mathrm{~B}_{3} \mathrm{~N}_{3}$ & 7 \\
\hline $\mathrm{B}_{0} \mathrm{~N}_{4}$ & 8 & $\mathrm{~B}_{3} \mathrm{~N}_{4}$ & 7 \\
\hline $\mathrm{B}_{1} \mathrm{~N}_{0}$ & 8 & $\mathrm{~B}_{4} \mathrm{~N}_{0}$ & 9 \\
\hline $\mathrm{B}_{1} \mathrm{~N}_{1}$ & 7 & $\mathrm{~B}_{4} \mathrm{~N}_{1}$ & 7 \\
\hline $\mathrm{B}_{1} \mathrm{~N}_{2}$ & 8 & $\mathrm{~B}_{4} \mathrm{~N}_{2}$ & 7 \\
\hline $\mathrm{B}_{1} \mathrm{~N}_{3}$ & 8 & $\mathrm{~B}_{4} \mathrm{~N}_{3}$ & 7 \\
\hline $\mathrm{B}_{1} \mathrm{~N}_{4}$ & 7 & $\mathrm{~B}_{4} \mathrm{~N}_{4}$ & 7 \\
\hline $\mathrm{B}_{2} \mathrm{~N}_{0}$ & 9 & $\mathrm{~B}_{5} \mathrm{~N}_{0}$ & 7 \\
\hline $\mathrm{B}_{2} \mathrm{~N}_{1}$ & 7 & $\mathrm{~B}_{5} \mathrm{~N}_{1}$ & 7 \\
\hline $\mathrm{B}_{2} \mathrm{~N}_{2}$ & 7 & $\mathrm{~B}_{5} \mathrm{~N}_{2}$ & 7 \\
\hline $\mathrm{B}_{2} \mathrm{~N}_{3}$ & 8 & $\mathrm{~B}_{5} \mathrm{~N}_{3}$ & $\mathrm{~B}_{5} \mathrm{~N}_{4}$ \\
\hline $\mathrm{B}_{2} \mathrm{~N}_{4}$ & 8 & & \\
\hline
\end{tabular}

Data pada tabel 7 menunjukkan bahwa rerata jumlah helaian daun terendah adalah 6 helai daun terdapat pada perlakuan $\mathrm{B}_{0} \mathrm{~N}_{0}$ yaitu pada perlakuan kontrol. Rerata jumlah helaian daun terbanyak adalah 9 helaian daun terdapat pada pelakuan $\mathrm{B}_{2} \mathrm{~N}_{0}$ (perlakuan $0,5 \mathrm{~kg}$ bokashi dan $0 \mathrm{~kg}$ pupuk NPK) dan perlakuan $\mathrm{B}_{4} \mathrm{~N}_{2}$ (perlakuan 1,6 kg bokashi dan 1 gram pupuk NPK). Selanjutnya hasil analisis sidik ragam pengaruh perlakuan bokashi dan pupuk NPK terhadap jumlah helaian daun kangkung darat disajikan pada tabel 8 .

Tabel 8. Hasil analis sidik ragam pengaruh perbedaan dosis bokashi dan pupuk NPK terhadap jumlah helaian daun kangkung darat.

\begin{tabular}{|l|c|c|c|c|c|}
\hline \multicolumn{1}{|c|}{ Sumber Keragaman } & DB & JK & KT & F. Hitung & $\begin{array}{c}\text { F. tabel } \\
0,05\end{array}$ \\
\hline Ulangan & 2 & 0,07 & 0,035 & & \\
\hline Perlakuan & 29 & 40,1 & 1,38 & & \\
\hline Bokashi (B) & 5 & 4,1 & 0,82 & 0,88 & 2,38 \\
\hline Pupuk NPK (N) & 4 & 3,6 & 0,9 & 0,97 & 2,52 \\
\hline B x N & 20 & 32,4 & 1,62 & 1,74 & 1,76 \\
\hline Galat & 58 & 53,93 & 0,93 & & \\
\hline Umum & 89 & 94,1 & 1,06 & & \\
\hline
\end{tabular}

Hasil analisis sidik ragam pengaruh perlakuan bokashi dan pupuk NPK terhadap jumlah helaian daun kangkung darat pada tabel 8 menunjukkan bahwa perlakuan bokashi tidak berpengaruh nyata terhadap jumlah helaian daun kangkung darat. Perlakuan pupuk NPK tidak berpengaruh nyata terhadap jumlah helaian kangkung darat. Interaksi bokashi dan pupuk NPK tidak berpengaruh nyata terhadap jumlah helaian daun kangkung darat. Hasil yang sama ditemukan oleh Raksun dan Japa (2018) yang menyimpulkan bahwa perlakuan bokashi tidak berpengaruh nyata terhadap jumlah daun kacang panjang. Selanjutnya dijelaskan bahwa perlakuan pupuk NPK tidak berpengaruh nyata terhadap jumlah helaian daun melon (Raksun, et al. 2019).

\section{Kesimpulan}

Berdasarkan hasil analisis data dan pembahasan pada penelitian ini dapat disimpulkan: (1) Aplikasi bokashi berpengaruh nyata terhadap tinggi batang, panjang helaian daun dan lebar helaian daun kangkung darat, tetapi tidak berpengaruh nyata terhadap jumlah helaian daun kangkung darat, (2) Perlakuan pupuk NPK berpengaruh nyata terhadap tinggi batang, panjang helaian daun dan lebar helaian daun kangkung darat, tetapi tidak berpengaruh nyata terhadap jumlah helaian daun kangkung darat, (3) Interaksi perlakuan bokashi dan pupuk NPK tidak berpengaruh nyata terhadap semua parameter pertumbuhan yang diukur, (4) dosis optimum bokashi 
untuk tanaman kangkung darat adalah $1,2 \mathrm{~kg}$ per $8 \mathrm{~kg}$ tanah, (5) dosis optimum pupuk NPK untuk tanaman kangkung darat adalah $1,5 \mathrm{~g}$ per tanaman.

\section{Ucapan Terima kasih}

Termakasih yang sebesar-besarnya tim penulis sampaikan kepada Rektor Universitas Mataram yang telah memfasilitasi pelaksanaan penelitian ini dengan menyediakan dana penelitian. Terimakasih juga kami sampaikan kepada semua pihak yang telah membantu pelaksanaan penelitian ini.

\section{Referensi}

Adnan, I. S., Utoyo, B., \& Kusumastuti, A. (2015). Pengaruh pupuk NPK dan pupuk organik terhadap pertumbuhan bibit kelapa sawit (Elaeis guineensis Jacq.) di Main Nursery. Jurnal Agro Industri Perkebunan, 3(2), 69-81. https://jurnal.polinela.ac.id/index.php/AIP/article/ view/20

Daryadi, D., \& Ardian, A. (2017). Pengaruh Pemberian Kompos Ampas Tahu Dan Pupuk Npk Terhadap Pertumbuhan Bibit Kakao (Theobroma Cacao L.) (Doctoral dissertation, Riau University). https://www.neliti.com/publications/201967/peng aruh-pemberian-kompos-ampas-tahu-dan-pupuknpk-terhadap-pertumbuhan-bibit-ka

Efendi, E., Purba, D. W., \& Nasution, N. U. (2017). Respon pemberian pupuk NPK mutiara dan bokashi jerami padi terhadap pertumbuhan dan produksi tanaman bawang merah (Allium ascalonicum L). Bernas, 13(3), 20-29. http://jurnal.una.ac.id/index.php/jb/article/view/13 $\underline{1}$

Firmansyah, I., Sayuran, B. P. T., Syakir, M., Sayuran, B. P. T., Lukman, L., \& Sayuran, B. P. T. (2019). Pengaruh Kombinasi Dosis Pupuk N, P, dan K Terhadap Pertumbuhan dan Hasil Tanaman Terung (Solanum melongena L.)[The Influence of Dose Combination Fertilizer N, P, and K on Growth and Yield of Eggplant Crops (Solanum melongena L.)]. http://repository.pertanian.go.id/handle/12345678 9/8044

Hasibuan, S., Mawarni, R., \& Hendriandy, R. (2017). Respon Pemberian Pupuk Bokashi Ampas Tebu dan Pupuk Bokashi Eceng Gondok terhadap Pertumbuhan dan Produksi Tanaman Kedelai (Glycine Max (L) Merril). Bernas, 13(2), 59-64. http://www.jurnal.una.ac.id/index.php/jb/article/vi $\underline{\text { ew/93 }}$

Idha, M. E., \& Herlina, N. (2018). Pengaruh Macam Media Tanam dan Dosis Pupuk NPK terhadap Pertumbuhan dan Hasil Tanaman Selada Merah (Lactuca sativa var. Crispa). Jurnal Produksi Tanaman, 6(3).

http://protan.studentjournal.ub.ac.id/index.php/pro tan/article/view/659

Lingga, P. \& Marsono (2013). Petunjuk Penggunaan Pupuk Edisi Revisi. Penebar Swadaya Jakarta.

Mulyana, D., Sakhidin, S., \& Iqbal, A. (2011). Pengaruh dosis bokashi terhadap pertumbuhan dan hasil tiga varietas padi. Agrin, 15(1) file:///C:/Users/ASUS/Downloads/115-215-1PB.pdf

Nurcahya, A. O., Herlina, N., \& Guritno, B. (2018). Pengaruh macam pupuk organik dan waktu aplikasi terhadap pertumbuhan dan hasil jagung manis (Zea mays saccharata Sturt). Jurnal Produksi Tanaman, 5(9). http://protan.studentjournal.ub.ac.id/index.php/pro tan/article/view/529

Pahan, I. (2008). Kelapa Sawit: Manajemen Agribisnis dari Hulu hingga Hilir. Penebar Swadaya, Jakarta-Indonesia, 412.

Raksun, A., \& Mertha, I. G. (2017). Pengaruh Bokashi Terhadap Produksi Cabai Rawit (Capsicum annuum). Jurnal Biologi Tropis, 17(2), 45-50. http://www.jurnalfkip.unram.ac.id/index.php/JBT/ article/view/435

Raksun, A., Japa, L., \& Merta, I. G. (2018). Pengaruh kompos kotoran kuda terhadap pertumbuhan Kacang panjang (Phaseolus vulgaris L). Jurnal Biologi Tropis, 18(2), 170-173. http://www.jurnalfkip.unram.ac.id/index.php/JBT/ $\underline{\text { article/view/778 }}$

Raksun, A., Japa, L., \& Mertha, I. G. (2019). Aplikasi Pupuk Organik dan NPK untuk Meningkatkan Pertumbuhan Vegetatif Melon (Cucumis melo L.). Jurnal Biologi Tropis, 19(1), 19-24. http://www.jurnalfkip.unram.ac.id/index.php/JBT/ article/view/1003

Raksun, A., Japa, L., \& Mertha, I. G. (2019). Pengaruh jenis mulsa dan dosis pupuk NPK terhadap pertumbuhan dan hasil tanaman terong hijau 
$\begin{array}{llr}\text { (Solanum melongena L). Jurnal Biologi } & \text { B } \\ \text { Tropis, 19(2) } & \end{array}$ http://www.jurnalfkip.unram.ac.id/index.php/JBT/ $\underline{\text { article/view/1115 }}$

Riry, N., Rehatta, H., \& Tanasale, V. L. (2018). Pengaruh Berbagai Komposisi Bokashi Ampas Biji Kakao dan Pemberian EM4 yang Berbeda terhadap Pertumbuhan dan Produksi tanaman Petsai (Brassica chinensis $\quad$ L.). Agrologia, 2(2). https://ojs.unpatti.ac.id/index.php/agrologia/article /view/268

Ryan, I. (2010). Respon Tanaman Sawi (Brasica juncea. L.) Akibat Pemberian Pupuk NPK dan Penambahan Bokashi pada Tanah Asal Bumi Wonorejo Nabire. Jurnal Agroforestri, 5(1), 310315 .

Setyastika, U. S., \& Suntari, R. (2019). PENGARUH APLIKASI BOKASHI TERHADAP DINAMIKA KETERSEDIAAN N, P, DAN S PADA INCEPTISOL KARANGPLOSO, MALANG. Jurnal Tanah dan Sumberdaya Lahan, 6(2), 1291-1299. https://jtsl.ub.ac.id/index.php/jtsl/article/view/277

Simatupang, Y. M. A. (1999). Pengaruh Pemberian Bokashi Kotoran Ayam dan Bokashi Rumput Terhadap Beberapa Sifat Fisika Tanah Podsolik Merah Kuning Gajrug dan Pertumbuhan Tanaman Kedelai (Glycine max L. Merr) varietas Wilis. Skripsi. Fakultas Pertanian Intitut Pertanian Bogor.

Sumiasri, N. U. R. U. L., \& Setyowati, N. I. N. I. K. (2006). Pengaruh beberapa media pada pertumbuhan bibit eboni (Diospyros celebica Bakh) melalui perbanyakan biji. Biodiversitas, 7(3), 260-263.

Sutedjo, H. (2010). Petunjuk Penggunaan Pupuk. Penebar Swadaya. Jakarta.

Sutedjo, M. M. (2010). Pupuk dan Cara Pemupukan. Cetakan-9. PT. Rineka Cipta. Jakarta.

Teutenburg, H. Shalabh (2009). Statistical Analysis of Designed Experiment.

Tomia, A. (2012). Pemanfaatan bokashi kotoran ternak ayam terhadap produktifitas tanaman caisin. Agrikan: Jurnal Agribisnis Perikanan, 5(2), 20-24.
https://ejournal.stipwunaraha.ac.id/index.php/AG RIKAN/article/view/138

Trisno, T., Widjajanto, D., \& Hasanah, U. (2016). Pengaruh Bokashi Kotoran Sapi Terhadap Beberapa Sifat Fisik Entisol Lembah Palu. AGROTEKBIS: E-JURNAL ILMU PERTANIAN, 4(3), 288-294. http://jurnal.faperta.untad.ac.id/index.php/agrotek bis/article/view/21

Wasis, B., \& Fathia, N. (2010). Pengaruh pupuk NPK dan kompos terhadap pertumbuhan semai gmelina (Gmelina arborea Roxb.) pada media tanaha bekas tambang emas (tailing). Jurnal Ilmu Pertanian Indonesia, 15(2), 123-129. http://journal.ipb.ac.id/index.php/JIPI/article/view/ $\underline{6496}$

Yousuf, M. N., Brahma, S., Kamal, M. M., Akter, S., \& Chowdhury, M. E. K. (2014). Effect of nitrogen, phosphorus, potassium, and sulphur on the growth and seed yield of coriander (Coriandrum sativum L.). Bangladesh Journal of Agricultural Research, 39(2), 303-309. https://www.banglajol.info/index.php/bjar/article/ view/20433

Yuliarti, N. (2009). 1001 Cara Menghasilkan Pupuk Organik. Yogyakarta.

Zulkarnain, Z. (2009). Dasar-dasar hortikultura. PT Bumi Aksara. https://repository.unja.ac.id/4053/ 